\title{
The application of a modified Monte Carlo method in the simulation of settlement pattern's spatial development in the example of Mstów (Śląskie voivodship, Poland)
}

Abstract

The first aim of the article is to propose the simulation of the settlement patterns development as an element of spatial planning methodology. In order to conduct such a simulation, a modified Monte Carlo method can be used. It approximates the spatial distribution of a studied phenomenon based on numerical calculations and implemented variables. Referring to previous works in which the method was applied, the author tested it on the village of Mstów. It was assumed that this method could highlight land features that are unreachable using traditional approaches in complex systems analyses.

The second aim was to investigate some of the determinants of contemporary spatial development. The conducted simulation demonstrated features of Mstów settlement pattern and proved determinants in its future development, including: the existence of areas especially predisposed for building, the decreasing number of new buildings being built, the decreasing importance of factors that were relevant in the past, and a significant relevance of the human factor. It was also proven that land development may occur on areas less predisposed to building.

Keywords

Mstów (Śląskie voivodship, Poland) • simulation • Monte Carlo method • settlement pattern $\bullet$ spatial development $\bullet$ land development

(c) University of Warsaw - Faculty of Geography and Regional Studies

Introduction

The contemporary role of spatial planning in the management of socio-economic development of areas is crucial. Both planned and predicted spatial changes are included in the planning documents. Due to this fact, it is necessary to continuously improve the quality of methodologies, both in terms of preparing new development plans, but also as far as evaluating already existing ones is concerned. What is more, it is not only vital to obtain a thorough knowledge about an area, but also to recognize its specificity. The author - following K.S. Christensen (1985) who wrote that, crucially, planning in general deals with uncertainty - suggests including a simulation of the development of settlement patterns as a part of the aforementioned activities. This enables one to face the problem of the uncertainties of a particular phenomena in space.

There are two main aims to this article. The first one is to present the application of a modified Monte Carlo method (MC) in order to simulate the spatial development of settlement patterns as a tool for improving the quality of spatial planning. In the paper, the author assumes that complex (territorial) systems (for instance settlement systems) cannot be analysed using traditional approaches. At the same time, such a simulation has not been used in Poland for this purpose. These reasons justify an attempt at using this more innovative solution. This aim also corresponded to steps taken toward developing a new local spatial development plan (Miejscowy Plan Zagospodarowania Przestrzennego. Polish acronym: MPZP) for the whole area of the village of Mstów, (the same research area as presented in this paper), taken by the Municipality Office of Mstów at the same
Oskar Wolski

Institute of Urban Development Department of Central-East Europe Development Studies, Poland e-mail: oskwolski@gmail.com

Received: 16 January 2015

Accepted: 14 April 2016

time that this article was submitted. Therefore, it was decided to apply the proposed method to this particular planning document, which will affect the subsequent course of the examination procedure. The second aim of the paper was to investigate the determinants of the spatial development of the study area.

Apart from the 'Introduction', the article consists of, , sections concerning: methodology, a description of the test procedure, an analysis of the results, conclusions and a summary.

The conducted simulation refers to the village of Mstów in the Silesian voivodship, where the office of the Mstów municipality is located, and which is the home village of the author. The choice of the test area is justified by the fact that in order to get the most out of the credibility of the simulation, it is important to have knowledge about the specifics of the area, which is also related to the simulation methodology.

The village of Mstów is located within the agglomeration of Częstochowa (Swianiewicz \& Klimska 2005), approximately $15 \mathrm{~km}$ east of the core city. It affects the dynamics of the suburbanisation processes present in the village and, as a consequence, the current changes in morphology of the settlement pattern. The village is located outside the close suburban zone of Częstochowa, a location where extensive forms of land use are dominant and where the landscape remains predominately rural (Wolski 2014). According to Lorens (2005), the above is typical of outer suburbanisation. Mstów covers $7.65 \mathrm{~km}^{2}$ and is inhabited by more than 1,700 citizens.

Particularly relevant is the fact that in the years 1279-1870 Mstów was a town (Kubicki 2011; Sobalski 1974; Jakubowski 1979). This 
is still reflected in its spatial features (e.g. the presence of market square). Nowadays, the village, apart from its administrative functions at the lowest level, serves local tourist and recreational functions.

\section{Literature review}

Up until now the Monte Carlo method has not been used in Poland for the purpose presented in this paper, and there are only a few examples, by J. Warszyńska (1980) and P. Werner (2003), when it comes to its use in the country. Abroad, the method is a very popular tool that is used to simulate the distribution of phenomena and determine the possibility of applied scenarios (mainly in research concerning physics, engineering, computer science, mathematics, material science, medicine, chemistry, genetics and biology, energy, and to a lesser extent, environmental science, earth and planetary science, among others). Concerning the use of the method in analysing and/or planning land development, MC was frequently used to quantitatively assess different models and scenarios. The following works, for instance, are noteworthy. G.D. Jenerette and J. Wu (2001) applied Monte Carlo to evaluate the model of a change in land use in Phoenix, Arizona, USA. For a similar purpose, i.e. to test previously developed models, C.Y. He et al. $(2002,2003)$ adopted MC in their research on the urban expansion of the city of Beijing, China. Shi et al. (2004), while adjusting land patterns in terms of ecological security, also tested their models using $M C$ in three research areas in China, including the capital city, precisely to simulate the development and determine the optimal weights,. In the work of Y. Liu et al. (2010), the distribution of new industries in the broader context of a strategic environmental assessment in the Dalian Municipality, China, was studied. A.J. Terando et al. (2014) used the method as a supplement in order to quantify their prediction on the intensity of urban sprawl in nine states of the southeast of the USA. As indicated by this short list, the adaptive MC method is used in connection with research on urbanisation in relation to land development, and responds to the dynamic and uncertain nature of the process.

The development and improvement of spatial planning methodology and the monitoring of the land use itself are not a new issues in geographical science. At least two works by Fogel (2012) and Korcelli et al. (2012) are worth mentioning. Both works refer to land use under existing restrictions. In the first work, 'Indicators of Spatial Policy Evaluation' were proposed to assist the spatial planning implementation. They are calculated with a suggested algorithm using land inventory results. The author proposes the simultaneous use of an orthophotomap and a loca spatial development plan for the area. The first is to set a real, current function of the area, while the second refers to a planned, future function. On the basis of this juxtaposition, as suggested, an evaluation of the rightness of the process of shaping area functions, is possible.

Korcelli et al. (2012) did research on the Warsaw metropolitan area. They constructed two alternative scenarios (which were later tested) of the future development, and change of land use, of the region based on spatial development trends. The scenarios, both reaching the 2025 time horizon, differ from each other in as far as the predicted values of the nine land use aspects are considered. To simulate the outputs of the scenarios they proposed a cellular automation model, supplying it with the MOLAND model. As a next step, land feasibility maps and numerical data were supplemented by maps of, inter alia, land use based on the Corine Land Cover system. The procedure proved that future land use patterns do depend on, and reflect, future development plans and underlined the necessity for spatial planning coordination.

\section{Methodology}

The Monte Carlo method ${ }^{1}$ is a mathematical method that allows the expression of the statistical estimation of a certain value of a studied phenomenon (Metropolis \& Ulam 1949). The Polish-American mathematician, Stanisław Ulam, is considered to be its inventor (Metropolis 1987). The method uses numerical calculation (it is an iterative numerical procedure (Werner 2003)) and implemented variables (Bartomowicz 2011) in order to simulate an arrangement of the selected features in space without the necessity of estimating the validity of choices made in the course of the analytical procedure, which - as it was underlined by Ratajczak (1999) - leads to many difficulties because the spatial location of a phenomenon depends on various natural and anthropogenic factors. In the simulation conducted for the purpose of this paper, positive stimulants and negative stimulants of spatial development were used as variables. On the basis of their relevance (expressed by a number of points) the area's potential map concerning the likelihood of building development was created. The map, a grid of squares applied to the borders of Mstów taken from its general map, was the starting material for the rest of the procedure. Each square had a point value that corresponded to the said potential.

For the sake of applying the greatest amount of randomness to events the (pseudo)random number generator (based on a computer algorithm) Research Randomizer 4.0 was used (available on-line at http://www.randomizer.org). The generator was programmed for continuous uniform (flat) distribution, so the probability of selecting a given basic field (square) did not affect the weighting (number of points)allocated to this field, which was based on the defined positive and negative stimulants of land development. In other words, through the use of this application the probability distribution of the random number generating process did not distort the weight of the point square, and thereby did not decrease the probability of selecting squares with the largest number of points, in favour of squares with a lower amount of points. As far as methods based on randomness of events are concerned, it is a key determinant of their reliability. Proceedings in the preparation of the matrix simulations and basic simulation proceeding, as well as the set of rules applied for land development for Mstów, are presented in the next chapter.

It should also be noted that the fact that a square was drawn, expresses only the probability of land development within this square. The more draws, the higher the probability of land development. At the same time, the probability is higher when compared to other squares that took part in the draw, and this probability cannot be expressed in absolute terms.

The demographic changes did not affect the methodology of the research procedure nor the simulation itself, which was proved as follows. In 1900 Mstów achieved its maximum demographic potential of 2,837 citizens (Lipiec 1974); whereas, in 1893 there were 233 buildings in the village (Topographic image 1893: Olsztyn, Częstochowa, Mstów. Based on the average rate of the increase in the number of buildings up until 2013, the author estimates that in 1900 the number of buildings could be greater by 19-21). Assuming that the past settlement network was sufficient to meet the needs of the inhabitants, it can be stated, with the later decrease in the number of citizens, that land developed independently: it was influenced by nondemographical factors. In view of the fact that in 2013, in Mstów, there were $583^{2}$ residential $^{3}$, and service and production

\footnotetext{
${ }^{1}$ Its theoretical foundations were profoundly described by A. Patrykiejew (1998).
}

${ }^{2}$ This number was determined by an inventory of land.

${ }^{3}$ Understood as detached houses and row houses. 
buildings ${ }^{4}$ with 1,742 citizens (data provided by the Municipality Office of Mstów), it can be concluded that the development of buildings was actually independent of the number of citizens and was due to structural and functional changes of the area. Due to this fact, the reliability of the conducted simulation was not distracted by - as was mentioned before - previous changes in demographic potential. At the same time, it is assumed that its future changes, which are extremely difficult to predict, will also not be of significance.

As proved by Wolski (2014), the increase in percentage of the built-up area in Mstów is a result of a change in function: one, recreational/tourist (building of tourist infrastructure base); and two, the fact that it is the central village of the municipality (attracting the building of commercial areas), which is partly in accordance with the meaning of 'outer suburbanisation'. Moreover, the increase of well-being in the village results from the fact that less people live in a single households.

The land development forecast for the Mstów area did not concern any specific period of time due to the fact that it is difficult to estimate the rate of rural spatial development (today it is 2.79 buildings per year). Nowadays it is influenced by, inter alia, the legislation of land use and spatial planning, different degrees of implementation of planning obligations by the municipal authorities, and endogenous factors. Hence, it was not possible to clearly determine at what time changes in space, of any intensity, would occur. (From the perspective of the application of the Monte Carlo method, it is not a mistake. According to Werner (2003) 'one of the most important elements is the verification of a sample from a random distribution model while the role of time factor is inexplicit'). The purpose of the simulation was to identify areas (basic fields) that are predisposed, and have the largest likelihood of being developed, and to determine the spatial directions and trends in land development.

\section{Research Procedure}

The research procedure in the context of the Monte Carlo simulation includes the following steps:

1) The creation of a grid of squares corresponding to the current location of buildings and the assignation of an appropriate colour to individual squares that shows the degree of building density. The colour scale is as follows: $100 \%$ - dark grey, $51 \%-99 \%$ - grey, $<50 \%$ - light grey (Fig.1). Plots immediately adjacent to houses (both detached and row houses) were also considered as built-up areas (according to the above mentioned scale of building density). In the case of the presence of a road in a square, the percentage of buildings for a square was calculated without that part covered by the road. Squares that were builtup to $100 \%$ or fully covered by a river were excluded from the simulation as areas that could not be developed further. Squares without any buildings were left blank.

2) The creation of a set of rules that governs spatial development in Mstów and the assignation of points to each of these, depending on the impact (or its lack) on a location of potential building. As a result, a relationship between land development opportunities and barriers and geographic location was expressed numerically (Tab. 1).

These factors are universal land development conditions, in reference to Mstów. This set of factors was presented to the author during studies at university as a part of the course 'Spatial analysis methods'. The factors - inspired by the work of Prawelska-Skrzypek (1985) - were generalised, grouped and simplified. The author modified them and applied them to Mstów using an expert method. The points were assigned arbitrarily with reference to the conditions of land development and the

${ }^{4}$ Understood as building complexes for a particular enterprise. degree of restriction listed in the spatial planning documents operative in the municipality. While creating the table, in the case of factors contributing to building, it was assumed - as the most important factor - the squares with the least percentage value had the highest probability of being invested in, provided that they meet, to the same degree as already built-up squares, the $1-5$ requirements. For instance, if two squares, one empty and the other having a $51 \%-99 \%$ built-up area, meet exactly the same requirements within the same spatial range, the first one is more likely to be built on than the one that has already been invested in. However, in the case of unfavourable factors it was decided that there is no significant relationship between building density within the squares and the disadvantages resulting from the previously mentioned factors, in the context of the location of new buildings. From the perspective of spatial development, unfavourable factors have the same spatial extent regardless of the fact that they were applied to empty areas or to those built-up to any percentage.

The size of a basic field - a square - was set at $80 \times 80 \mathrm{~m}$. Consequently, the area of the village was divided into 1,437 squares, which was sufficient for the purposes of the research. Also considered was the individual predisposition of each fragment of the area of the village for development in terms of their ability to absorb the benefits of their geographical proximity and accessibility factors which were listed in the table .

The table was created in line with a ten-point range for each factor: from +5 (maximum) to -5 (minimum, there was no 0 ) based on expert assessment. It should be noted that not all the point values for each column and row had their real application. For example, within the area of an ecological site in Golizna, there are only undeveloped squares; however, the author felt obliged to allocate points to squares that represented hypothetically developed areas.

At the time the research procedure was conducted (2014), local authorities in the Mstów municipality had already taken initial steps to prepare a new MPZP. As a result, the purpose of the simulation was to contribute to the methodology for the preparation of this planning document. What is more, in the opinion of the author, the current and still operative MPZP was/ is not effective, and is elaborated a bit intuitionally and with little awareness of the factors determining building development listed in the article. Consequently, the planning document to which these factors were referred, was the study of conditions and directions of spatial development (Studium uwarunkowań i kierunków zagospodarowania przestrzennego. Polish acronym SUiKZP) ${ }^{5}$ for the Mstów municipality (Fig. 2), later referred to in the text and in the Table 1 as 'the study'. It was also chosen because of its strategic nature and spatial development legislation: the study is superior to the local spatial development plan (not vice versa. Physical Planning and Spatial Development Act 2003).

It must also be noted that in Mstów the areas that can be built on, according to current MPZP, cover about $13 \%\left(\sim 1 \mathrm{~km}^{2}\right)^{6}$. This oversupply may affect the process of the dispersion of land development even though the area able to be developed is highly concentrated in the northern part of the village.

The first factor taken into consideration was the distance from the seventeenth-century built-up area of Mstów, the spatial scope of which covers the historical area of the former town and can be called 'the centre'. It was decided that, in most cases,

${ }^{5}$ Both the study of conditions and directions of spatial development (SUiKZP) and local spatial development plan (MPZP) are use-based planning documents. However, under Polish conditions, only the first one is obligatory, while only the second is a by-law. For more information concerning the basis of the planning obligation, the tools of spatial management and its legislation in Poland, non-Polish readers can see for instance: Mierzejewska 2009 or Parysek 2009.

${ }^{6}$ The percentage was calculated by the author, georeffering a raster file with SUiKZP map and using a measurement option available in ArcGIS 10.3. 


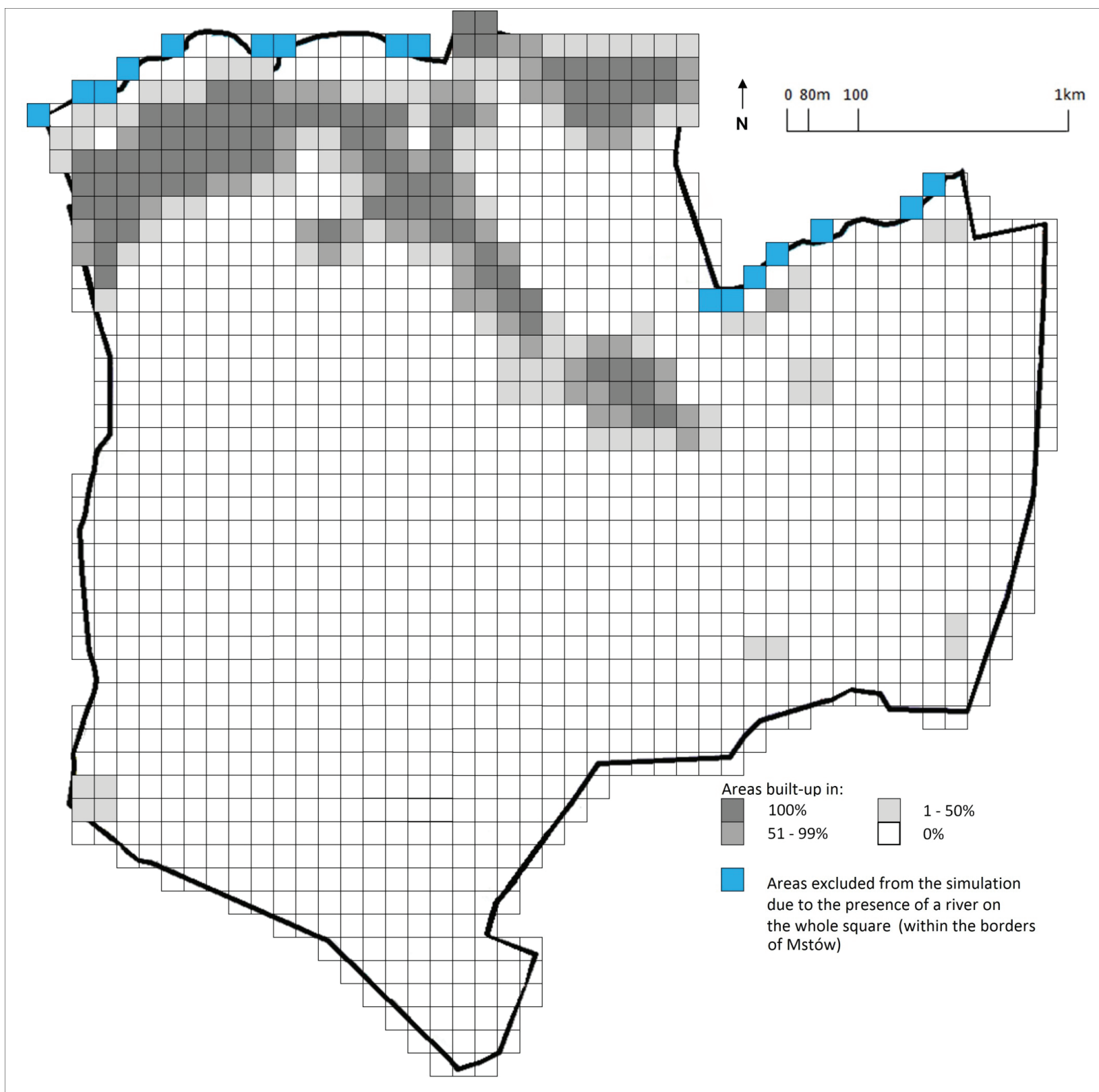

Figure 1. The degree of building density in Mstów

Source: own work

A grid of squares applied to the borders of Mstów showing the current location of buildings. The colours assigned to squares (depending on a various percentage of buildings), indicate the degree to which an individual square is built-up and the areas excluded from the simulation due to a river.

building development proceeds from the centre outwards. The second condition, much easier to estimate, was the impact of the main roads on the spatial development. Less importance was assigned to local roads (factor no. 3, Tab. 1).

Factor no. 4 included the geographical proximity of areas that had already been invested in. It is easier to create new or to upgrade buildings that are close to already existing ones (easier services provision for example. Tab. 1).

The next two factors (no. 5 and no. 6) were directly related to study decisions. Based on this document, areas predisposed and not predisposed to the investment were defined. Squares included in functional areas (Fig. 2): M1, M2, M3, R and US1 were assigned to the first group, which obtained positive points whereas squares included in functional areas Rz, RMU, ZC, UZP,
US2, icp and those requiring the consolidation and division of a property were assigned to the second group, which obtained negative points (Tab. 1). This division is consistent with the decisions made on these areas, and the point values for the squares match the degree of restrictions provided by the study ${ }^{7}$. If a square was in a range of more than one functional area, its point

${ }^{7}$ The study does not state a percentage up to which the area within those functional areas can be built. However, the study presents zones of building areas which have maximum percentages of development stipulated: zone no. I can be built up to $100 \%$ and zone III no. up to $40 \%$ (there is no percentage stipulated for zone no. II, but it is not present in Mstów). Given the fact that the area of the zone no. III overlaps the area of the functional areas M1, M2, M3, R and US1 to a considerable degree, this may affect negatively correctness of the research procedure in this article. Nevertheless, this deliberated simplification was applied to make the description of the procedure clearer and does not affect usefulness of the method as such. 
Table 1. Positive and negative stimulants for land development in the area of Mstów. The relation between stimulants and the degree of building density expressed with points

\begin{tabular}{|c|c|c|c|c|}
\hline $\begin{array}{l}\text { Item } \\
\text { no. }\end{array}$ & Stimulant & $\begin{array}{l}\text { Empty } \\
\text { square }\end{array}$ & $\begin{array}{c}\begin{array}{c}\text { Square built-up } \\
\text { to } 1-50 \%\end{array} \\
\end{array}$ & $\begin{array}{l}\text { Square built-up } \\
\text { to } 51-99 \%\end{array}$ \\
\hline \multirow{3}{*}{1.} & \multicolumn{4}{|c|}{ The distance from the historical urban centre (boundaries of the seventeenth-century town): } \\
\hline & a) up to $200 \mathrm{~m}$ & +5 & +4 & +3 \\
\hline & b) $201-400 \mathrm{~m}$ & +3 & +2 & +1 \\
\hline \multirow{3}{*}{2.} & \multicolumn{4}{|c|}{ The distance from the main roads (regional road DW 786 and sub-regional roads/streets: Częstochowska, Wolności): } \\
\hline & a) up to $80 \mathrm{~m}$ & +5 & +4 & +3 \\
\hline & b) $81-200 \mathrm{~m}$ & +4 & +3 & +2 \\
\hline 3. & $\begin{array}{c}\text { The distance from the most important local roads (Kilińskiego, Norwida, } \\
\text { Chopina, Partyzantów, Kościelna, Ogrodowa, Widokowa, 16-egoStycznia) } \\
\text { up to } 80 \text { m, excluding squares defined in point } 2 .\end{array}$ & +3 & +2 & +1 \\
\hline \multirow{3}{*}{4.} & \multicolumn{4}{|c|}{ The surroundings and distance from already invested areas up to $80 \mathrm{~m}:$} \\
\hline & a) in two or more directions & +5 & +4 & +3 \\
\hline & b) in one direction & +3 & +2 & +1 \\
\hline \multirow{6}{*}{5.} & \multicolumn{4}{|c|}{ Predisposition to development according to SUiKZP - functional areas: } \\
\hline & a) M1 & +5 & +4 & +3 \\
\hline & b) M2 & +4 & +3 & +2 \\
\hline & c) $\mathrm{M} 3$ & +1 & +1 & +1 \\
\hline & d) $R$ & +1 & +1 & +1 \\
\hline & e) US1 & +1 & +1 & +1 \\
\hline \multirow{6}{*}{6.} & \multicolumn{4}{|c|}{ Development prohibition according to SUIKZP - functional areas: } \\
\hline & a) $R z$ & -5 & -5 & -5 \\
\hline & b) RMU & -3 & -3 & -3 \\
\hline & c) ZC & -5 & -5 & -5 \\
\hline & d) UZP \& US2 & -3 & -3 & -3 \\
\hline & e) icp & -5 & -5 & -5 \\
\hline 7. & Market square including Plac Mickiewicza street & -5 & -5 & -5 \\
\hline 8. & High and very high voltage power line impact zone & -2 & -2 & -2 \\
\hline 9. & $\begin{array}{l}\text { Warta river, Tasarki reservoir, flood risk } \\
\text { (values do not add up in the individual squares) }\end{array}$ & -5 & -5 & -5 \\
\hline 10. & Forests, afforestation areas and wetlands & -3 & -3 & -3 \\
\hline 11. & Golizna ecological site & -4 & -4 & -4 \\
\hline 12. & The requirement for consolidation and division of property & -2 & -2 & -2 \\
\hline
\end{tabular}

Source: own work

value was calculated using the arithmetic mean of the scores for these areas separately, rounded up to unity for positive values or down to unity for negative values. When a square covered both a functional area and non-functional area, according to the study of the conditions, (for example ZN,WS or flood-prone areas; Fig. 2), the point value was assigned according to criteria presented in Table 1, providing that the functional area covered at least $51 \%$ of a square.

The author also defined other factors for areas that were unfavourable for land development (no. 7-12) based on the study (Fig. 2), the general map of the village of Mstów (Fig. 3) and an inventory of land results; they were: the impact of high and very high voltage power lines, flood risk, the presence of forests, afforestation areas and wetlands, the Golizna ecological site, requirement for consolidation and division of property and the specificity of the market square in Mstów. The risk of flooding and the presence of the market square - an area that, by its nature, precludes building development - were considered as the most important negative stimulants for spatial development (Tab. 1). The mentioned factors were granted the maximum negative number of points since the probability of cubature building location within them is extremely small due to a current awareness of the risk connected with the location of buildings in flood-prone areas, as well as the awareness of the need for culture heritage preservation. Environmental factors were considered less important: forests, afforested areas, wetlands and clusters of valuable plant communities (ecological sites. Tab.1). Building locations within these areas is potentially possible and depends mainly on how closely the terms agreed in the existing planning documents of the municipality of Mstów are going to be followed. Often, in the case of the area of analysis, it happened that forest areas were sacrificed for the development of a settlement. 


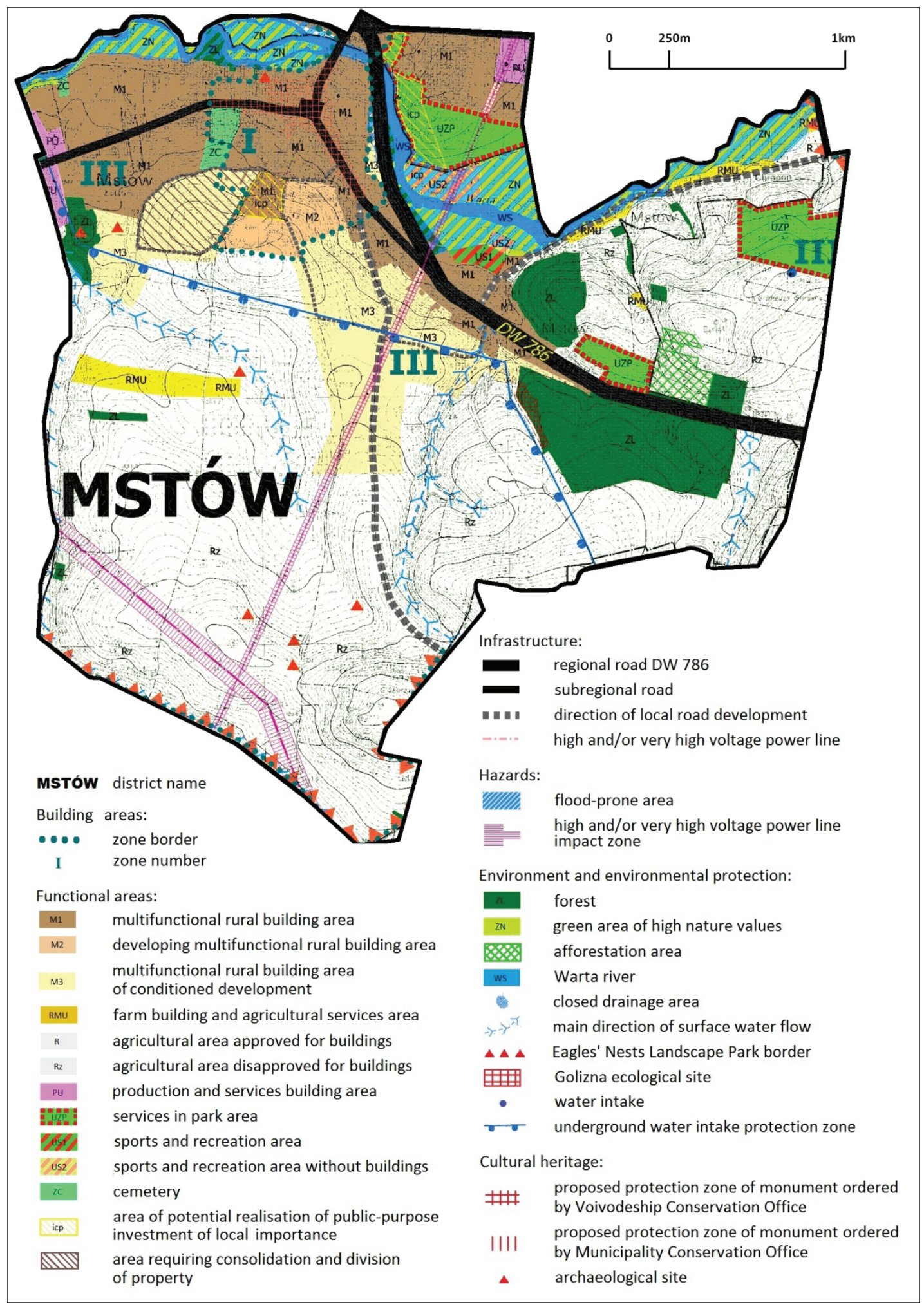

Figure 2. A fragment of the map for the study of conditions and directions of spatial management for the Mstów municipality showing the village of Mstów

Source: Study of conditions and directions of spatial development for the Mstów municipality 2012; modified by the author.

A fragment of map presenting the decisions of the study for conditions and directions of spatial management for the Mstów municipality, for the area of the village of Mstów. The data provided in the map served to elaborate land development positive and negative stimulants (item number: 1, 5, 6, 8, 9, 10, 11 and 12 according to table 1). 


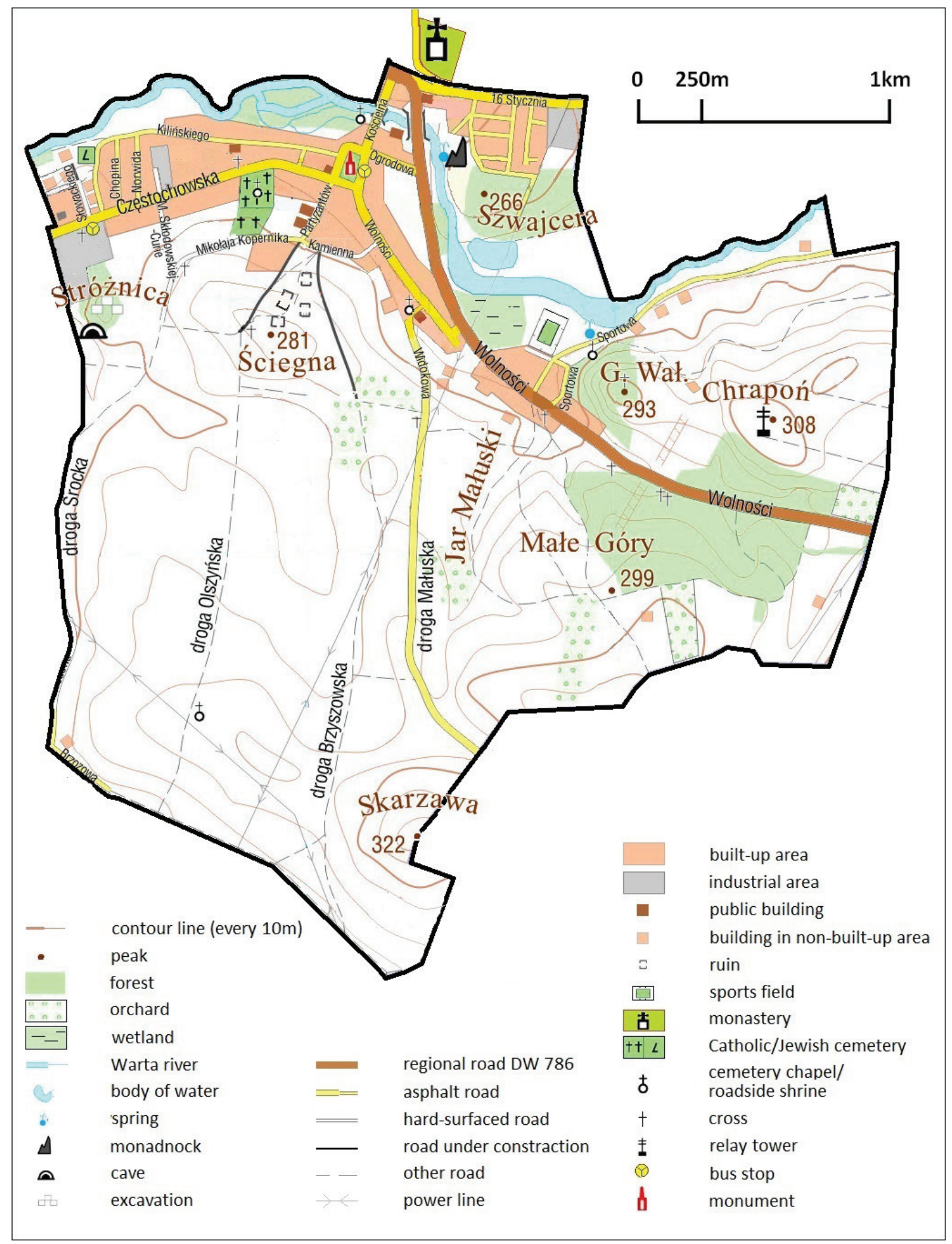

Figure 3. General map of the village of Mstów

Source: Tourist map. Mstów 2011: modified and supplemented by the author

A fragment of a general map of the Mstów municipality showing the area of the village of Mstów. The map served to elaborate land development positive and negative stimulants (item number: 2, 3, 4, 7, 9 and 10 according to table 1). 
Moreover, an ecological site is not a restrictive enough tool for environment conservation to rule out the possibility of a change to the form of land use.

Other negative development factors for Mstów are high and very high voltage power lines, and a requirement for the consolidation and division of property (Tab. 1). In the first case, there is a threat to the health of residents in the area of impact, whereas in the second case the legal status of a plot is unclear, which limits the possibility of their acquisition and/or development.

The simulation also incorporated the illogicality of human behaviour; it was considered potentially possible to create a building in areas such as the market square or cemetery, although it is commonly known that these areas are excluded from further development. In such cases, the squares were granted the largest possible negative value.

3) The creation of a map with a total point weight assigned to each square. The weight was calculated by the number of points received by the square based on the outlined negative and positive stimulants of land development (Fig. 4). This map has been developed through a series of overlapping sub-maps corresponding to the score for each factor separately.

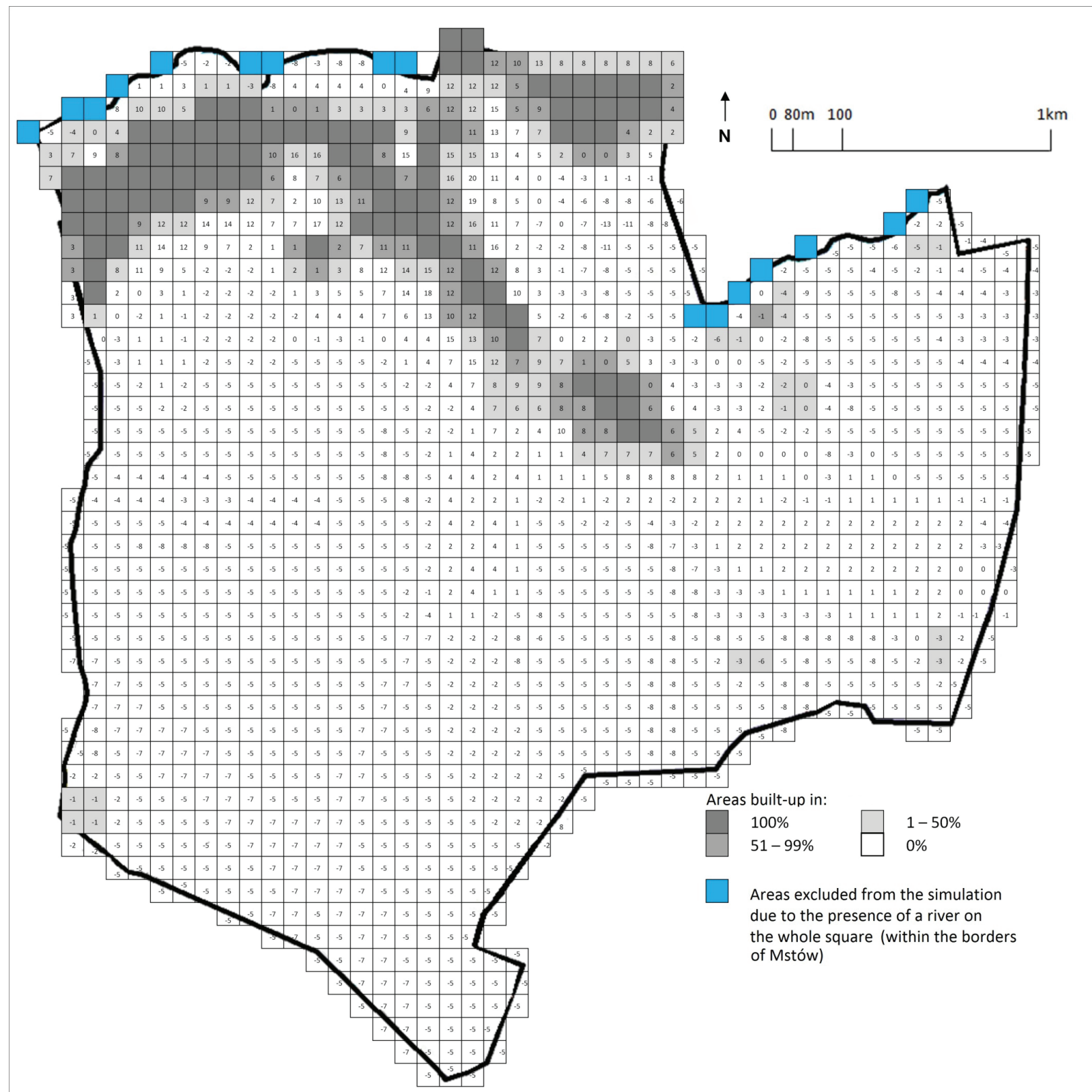

Figure 4. The map of total point weights based on the positive and negative land development stimulants Source: own work

A grid of squares applied to the borders of Mstów showing the current location of buildings, the areas excluded from the simulation due to a river and the potential of each square to be invested in. For each square that has the possibility of development there are assigned: 1) the colour, indicating the degree to which the square is built-up, and 2) the total point weight calculated based on the positive and negative stimulants of land development in the area of analysis. The weight expresses the probability of land development in each square before the simulation. 
4) The creation of the simulation matrix (Fig. 5) based on the map of total point weight within the squares on which prospective development is possible, by assigning each square a sequence of numbers corresponding to the total point weight, in such a way that the probability of selecting the number connected with the square reflects the total point weight of a given square. For example, the square V10 was granted a weight of 16 points, and the range 946-961, assigned to this square, was granted after the placement of the square within the matrix of the simulation. While the last square, PP26, located in the range of 1812 to 1813 , represents the sum of all points from all squares, i.e. 1813 .
5) The generation of random numbers using the application Research Randomizer 4.0 within the numerical range of the squares (1-1813). In view of the fact that only 326 squares $(22.6 \%)$ can be invested in (Out of the total number of 1,437 squares: 92 squares were $100 \%$ built-up according to the meaning of the word as described in the Methodology section, 16 squares were excluded due to the fact that they were fully covered by a river, and 1003 squares were excluded because of a non-positive total point weight), and the total weight of each ranged from 1 to 20 , it was decided that in order to keep the highest possible randomness, 326 random numbers had to be generated. It was derived from the true logical-probabilistic

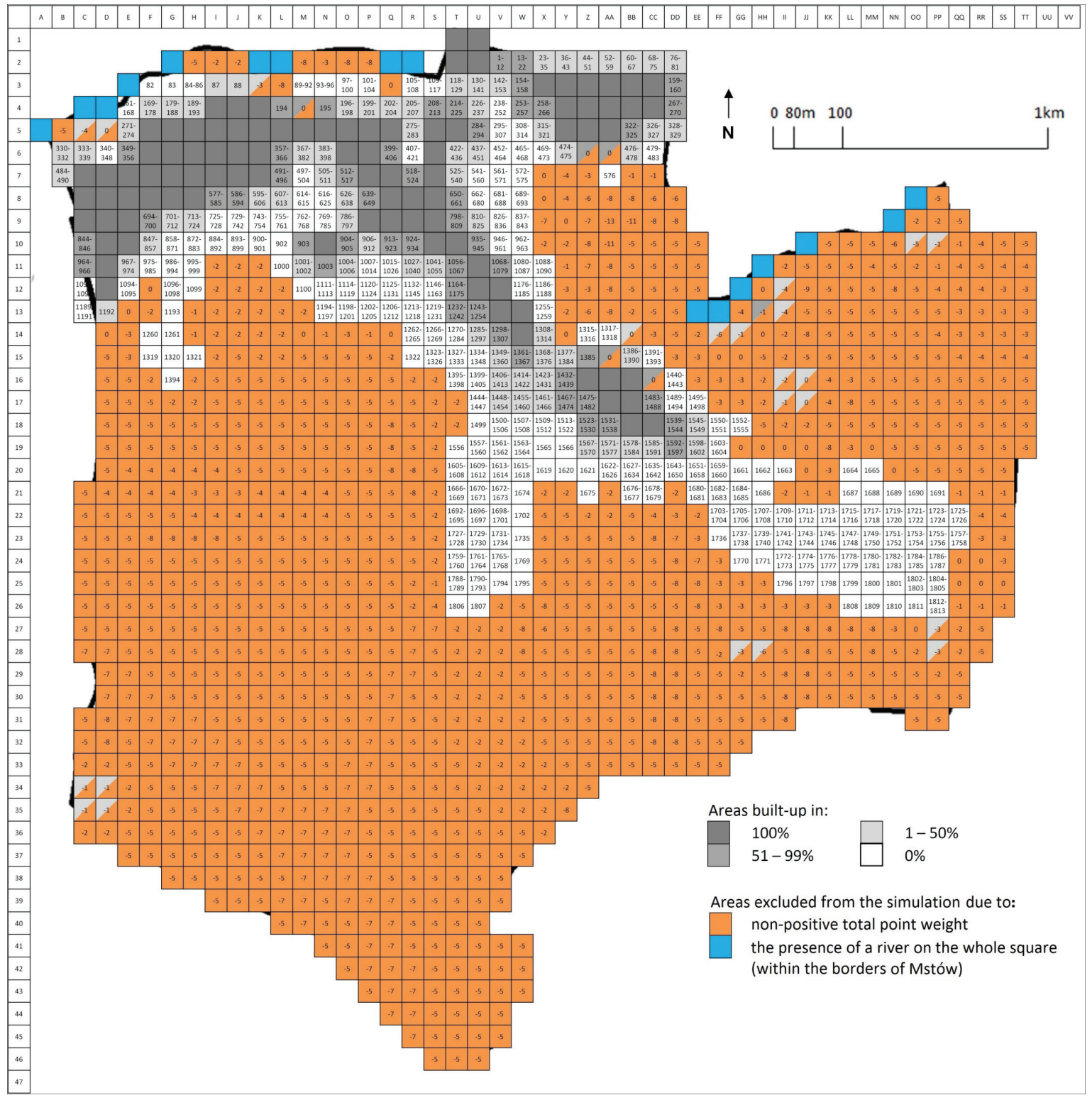

Figure 5. Mstów land development simulation matrix

Source: own work

Simulation matrix made from the map of total point weights by assigning each square with the possibility of development a sequence of numbers corresponding to the total point weight obtained by the square on the basis of the positive and negative land development stimulants. The range of numbers connected with the square reflects its total point weight and the probability of it being developed before the simulation at the same time. The last square, PP26, located in the range of 1812 to 1813, represents the sum of all points from all squares, i.e. 1813. 
MISCELLANEA GEOGRAPHICA - REGIONAL STUDIES ON DEVELOPMENT

Vol. 20 • No. 3 • 2016 • pp. 19-31 • ISSN: 2084-6118 • DOI: 10.1515/mgrsd-2016-0016

assumption, in accordance with continuous uniform distribution, that by drawing 326 numbers (where each can be drawn only once), each square, where squares have different total point weights, is likely to be drawn proportionally to its weight. Therefore, by drawing 326 numbers in the range of 1 to 1813 , it was certain that a square with the weight of 20 points will be 20 times more likely to be drawn than a square with a weight of only 1 point (however, it does not mean that it is certain that such a square will be drawn a proportionately greater number of times). Generated numbers are presented in Table 2.

Analysis of simulation results and conclusion

Based on the results of the simulation it was concluded that (Fig. 6):

1) Land development within the borders of the village is, and probably will continue to be, of high spatial concentration. As was mentioned, in the procedure of the simulation only 326 squares were taken into account (22.6\%). These squares qualified as far as building development based on positive and negative stimulants was concerned. This situation clearly demonstrates a concentration of possible investment zones.

2) Undeveloped areas in Mstów will be reduced. The research included 210 undeveloped squares but, during the simulation, as many as 95 were designated to be developed and 36 among them were drawn more than once.

3) It is more likely that new buildings will be created on areas (basic fields) not yet invested in than on areas already developed (to various degrees). Out of the 180 drawn squares, empty squares were drawn the most frequently(95 times), while squares built-up to $1-50 \%$ were drawn 48 times and those builtup to $51-99 \%$ only 37 times.

4) The intensity of new buildings in Mstów will tend to decrease. Most of the squares were drawn once (in this case102 squares; 41 squares were drawn twice; 21 squares were drawn three times -, 10

Table 2. Random numbers generated under continuous uniform (flat) distribution in the range 1-1813 used in the simulation. Shown in the order obtained

\begin{tabular}{|c|c|c|c|c|c|c|c|c|}
\hline 1274 & 1233 & 625 & 129 & 62 & 683 & 964 & 1695 & 50 \\
\hline 947 & 522 & 457 & 764 & 1607 & 525 & 143 & 20 & 1734 \\
\hline 126 & 1374 & 499 & 1708 & 222 & 707 & 812 & 1323 & 1148 \\
\hline 1715 & 33 & 1158 & 973 & 797 & 1091 & 566 & 1317 & 1571 \\
\hline 1133 & 660 & 634 & 253 & 509 & 845 & 570 & 193 & 1412 \\
\hline 745 & 545 & 1492 & 1804 & 538 & 1497 & 1187 & 432 & 734 \\
\hline 269 & 842 & 35 & 939 & 185 & 130 & 653 & 719 & 472 \\
\hline 787 & 769 & 1627 & 346 & 900 & 1753 & 1302 & 1718 & 828 \\
\hline 712 & 198 & 632 & 516 & 12 & 1717 & 91 & 1234 & 843 \\
\hline 1624 & 546 & 1245 & 1060 & 953 & 34 & 2 & 435 & 1430 \\
\hline 289 & 52 & 510 & 76 & 314 & 911 & 1055 & 96 & 1711 \\
\hline 72 & 1310 & 1518 & 1807 & 883 & 377 & 796 & 351 & 1687 \\
\hline 929 & 618 & 201 & 192 & 675 & 349 & 153 & 1189 & 567 \\
\hline 1699 & 1346 & 1500 & 164 & 1523 & 1281 & 889 & 925 & 983 \\
\hline 345 & 1356 & 1171 & 646 & 282 & 231 & 1773 & 1173 & 1520 \\
\hline 1640 & 1145 & 1439 & 1745 & 6 & 160 & 191 & 307 & 442 \\
\hline 1723 & 662 & 1537 & 10 & 1093 & 100 & 331 & 995 & 827 \\
\hline 1730 & 83 & 610 & 620 & 482 & 1195 & 178 & 740 & 1371 \\
\hline 1248 & 354 & 317 & 189 & 73 & 1806 & 645 & 1446 & 957 \\
\hline 961 & 374 & 835 & 773 & 1216 & 147 & 750 & 864 & 743 \\
\hline 604 & 1322 & 247 & 817 & 228 & 1735 & 3 & 728 & 275 \\
\hline 863 & 1653 & 673 & 1625 & 506 & 1272 & 709 & 1712 & 1701 \\
\hline 867 & 1077 & 561 & 1563 & 99 & 332 & 1458 & 365 & 420 \\
\hline 112 & 1802 & 92 & 496 & 1531 & 1041 & 881 & 169 & 1623 \\
\hline 1392 & 801 & 1137 & 312 & 681 & 926 & 1002 & 934 & 1791 \\
\hline 1223 & 210 & 1254 & 65 & 868 & 410 & 1656 & 1453 & 1131 \\
\hline 406 & 1681 & 241 & 1762 & 1605 & 1135 & 237 & 308 & 1691 \\
\hline 1716 & 16 & 1219 & 815 & 121 & 369 & 227 & 1132 & 987 \\
\hline 1467 & 323 & 1682 & 1396 & 664 & 598 & 969 & 878 & 1528 \\
\hline 951 & 1159 & 1539 & 1351 & 684 & 1230 & 1294 & 484 & 372 \\
\hline 303 & 895 & 342 & 529 & 988 & 1332 & 694 & 697 & 822 \\
\hline 1795 & 341 & 606 & 1385 & 1496 & 872 & 1028 & 1672 & 923 \\
\hline 1408 & 1178 & 1444 & 820 & 55 & 1277 & 1370 & 629 & 426 \\
\hline 992 & 850 & 468 & 824 & 1217 & 1099 & 1700 & 1468 & 152 \\
\hline 267 & 123 & 119 & 1534 & 591 & 1565 & 613 & 446 & 1336 \\
\hline 1199 & 17 & 637 & 667 & 1662 & 1738 & 1035 & 42 & 556 \\
\hline 1671 & 557 & & & & & & & \\
\hline
\end{tabular}

Source: Research Randomizer 4.0. 


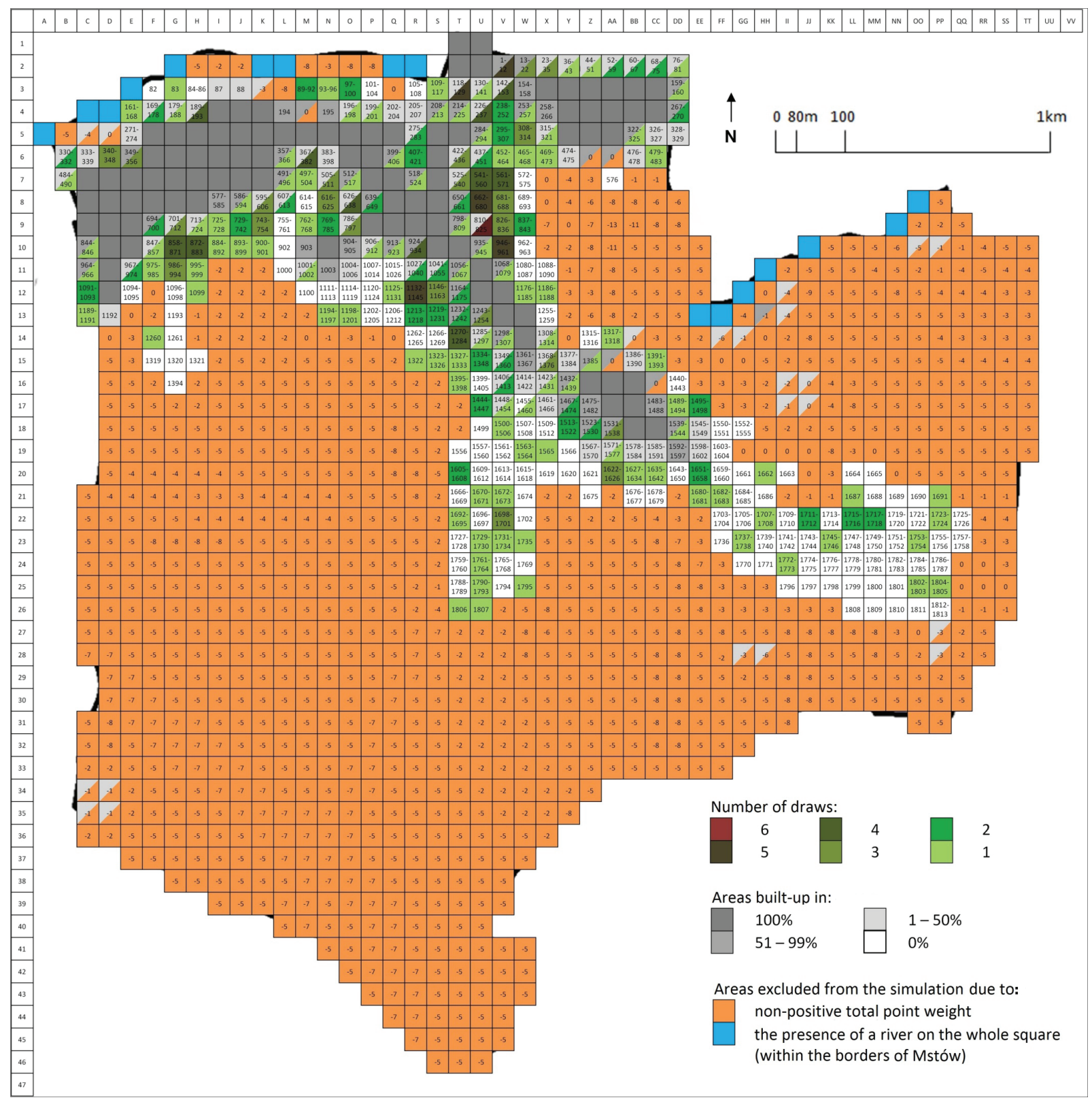

Figure 6. Intensity and spatial directions of land development in Mstów based on the generated (pseudo)random numbers Source: own work

A map showing the results of the simulation: 1) intensity, expressed by the number of draw(s) for each square with the possibility of development, and 2) spatial directions of new buildings. Draws were made on the basis of the generated numbers through Research Randomizer 4.0 (pseudo) random numbers, from the number range 1-1813, which covers the sum of the total point weights of all the squares where development is possible.

squares were drawn four times -, 5 squares five times; and 1 square six times), which suggests that the nature of spatial development of the village will be similar to low intensity development .

5) In the area of analysis there were zones particularly predisposed to building development. There are three main sectors where new clusters of buildings will be concentrated. The first one is within the squares labelled U-V7, U8, U9, V10 where the number of draws was between 4 and 6 ; the second for squares labelled G-H10, G11, which were drawn 3-4 times; and the third for squares labelled R-S12, R-S13, T14, which were drawn $2-5$ times. It should be noted that only one square, from those mentioned above, is currently developed (U9; at less than $51 \%$ ). Therefore, the clusters of new investments will be created mainly in the areas not yet developed. The common features of all three sectors are there proximity to major transportation routes and areas already invested in as well as non-peripheral location. It shows what kind of land development factors will be of utmost importance in the area of Mstów in the future.

6) Land development in the village is prone to form a unity, that is, not to be scattered. It can be observed that in many cases if the drawn squares were invested in, it would connect hitherto separately developed areas. Such 'connectors' could be, for 
example, the squares W-V5, V-U6, T6. These squares connect the centre of Mstów to the northern residential area and also to X15, $X-Y 16$, which unifies buildings along the regional road (DW 786).

7) Buildings will also probably be located in very poorly invested in, peripheral areas that are not closely connected to presently developed zones. Such locations will not be based on a number of factors simultaneously. What is more, land development there can be seen as relatively intense (more than one draw. for example squares: V22, JJ22, LL22, MM22 where potential building development might be influenced by the proximity of a road).

8) The spatial development of Mstów could also be present in 'special' areas, historically and contemporarily not subject to any buildings (market square, cemetery), by taking into account only positive and negative building development stimulants. The author deliberately confronted the attributes of development of buildings and their directions with the logic of human behaviour, in order to prove how important the role of planning and cultural factors are in the development of an area. Assuming the illogicality of human behaviour, it can be argued that in the market square (R6) or in the cemetery (the area within the squares labelled L-N 6-7 and L9) there are favourable conditions for spatial development.

9) Building development is not only said to advance in those areas and directions most predisposed to it. It was proven that when the likelihood of land development is assessed on the basis of a particular set of determinants (this type of assessment occurs in most planning studies), its advancement can occur at higher intensity in areas theoretically less favoured. For example, squares $\mathrm{U} 10$ and V10 were selected the same number of times (4), despite the fact that the first one received twice the total point weight (20 points versus 10 points), which, moreover, happened to be the highest total weight of all those allocated. It results from the fact that a high probability of certain events only increases the chances of their occurrence, but does not guarantee an increase in the intensity of these events in the future. One can even argue that it is desirable to consider a random course of certain phenomena and processes during planning procedures (especially in the early stages, when the development is not subject to any conditions or obligations and has a greater 'spontaneity').

\section{Summary}

The presented conclusions relate to the simulation performed on the basis of the first (pseudo)random generated set of numbers which were sufficient for the research.

The conclusions of the simulation performed allow the author to conclude that the proposed modified Monte Carlo method can be successfully used to improve the quality of planning studies. Because of the fact that planners need to solve real 'problems' occurring in space, which of course is not always predictable, it can be stated that the application of the proposed method will effectively fill an existing methodological gap in the field of the prognosis of such phenomena. The method also presents a number of regularities in building development in the area of analysis, which are difficult to observe and understand without the performance of such simulations. According to the author, these are the most important arguments for including it in the methodology of preparation and - to a lesser degree -evaluation of planning documents.

Needless to say, the author's use of the modified Monte Carlo method was only an example of how helpful tool this method can be in order to simulate the course of phenomena. The method can also certainly be adopted for the purposes of the simulation of not only land development and its direction but also other areas that have a 'spatial' nature.

\section{Acknowledgements}

The author would like to thank the anonymous reviewer for their accurate remarks and the time spent on reading the article.

\section{References}

Bartłomowicz, T 2011, 'Symulacja Monte Carlo jako narzedzie prognozowania wybranych aspektów rynku nieruchomości' in Modelowanie i prognozowanie zjawisk społecznogospodarczych, ed J Pociecha, Uniwersytet Ekonomiczny, Kraków, pp. 119-128.

Christensen, KS 1985, 'Coping with uncertainty in planning', Journal of the American Planning Association, vol. 51, no. 1 , pp. 63-73.

Fogel, P 2012, 'Wskaźniki oceny polityki i gospodarki przestrzennej w gminach', Biuletyn KPZK PAN, vol. 250, ed P Fogel.

$\mathrm{He}, \mathrm{CY}$, Shi, PJ, Chen, J \& Xu, XL 2002 'Study on the process and mechanism of urbanization in Beijing area', Acta Geographica Sinica, vol. 57(3), pp. 363-371.

$\mathrm{He}, \mathrm{CY}$, Chen, J, Shi, PJ \& Fan, YD 2003 'City expansion model of metropolitan area in China: a case study of Beijing', Acta Geographica Sinica, vol. 58(2), pp. 294-304.

Jakubowski, Z 1979, Biuletyn informacyjny, Biuro badań i dokumentacji zabytków, Częstochowa.

Jenerette, GD \& Wu, J 2001, 'Analysis and simulation of landuse change in the central Arizona - Phoenix region, USA', Landscape Ecology, vol. 16, no. 7, pp. 611-626.

Korcelli, P, Grochowski, M, Kozubek, E, Korcelli-Olejniczak, E \& Werner P, 2012, 'Development of Urban-Rural Regions. From European to Local Perspective', Institute Of Geography And Spatial Organization, Polish Academy Of Sciences Monographies, vol. 14, Warszawa.
Kubicki, A 2011, Z przeszłości Mstowa. Notatki kronikarskie od średniowiecza do 1939, Drukarnia usługowa "Gryf", Częstochowa.

Lipiec, J 1974, 'Noty historyczne ważniejszych miejscowości powiatu częstochowskiego', Ziemia Częstochowska, vol. X ed M Stańczyk, Towarzystwo Popierania Kultury Regionalnej, Częstochowa, pp. 505-518.

Liu, Y, Chen, J, He, W, Tong, Q \& Li, W 2010, 'Application of an uncertainty analysis approach to strategic environmental assessment for urban planning', Environmental Science \& Technology, vol. 44, no. 8, pp. 3136-3141.

Lorens, P 2005, 'Suburbanizacja $\mathrm{w}$ procesie rozwoju miasta postsocjalistycznego' in Problem suburbanizacji, ed $\mathrm{P}$ Lorens, Urbanista, tom 7, Warszawa, pp. 33-44.

Mapa turystyczna. Gmina Mstów (Tourist map. Mstów) 2011, 1:25 000, Compass, Kraków.

Metropolis, N 1987, 'The beginning of the Monte Carlo method', Los Alamos Science. Special Issue 1987, pp. 125-130. Available from: <http://library.lanl.gov/la-pubs/00326866 pdf>. [18 November 2014].

Metropolis, N \& Ulam. S 1949, 'The Monte Carlo Method', Journal of the American Statistical Association, vol. 44, no. 247, pp. 335-341. Available from: <http://web.maths.unsw.edu.au/ $\sim$ peterdel-moral/MetropolisUlam49.pdf>. [24 November 2015].

Mierzejewska, L 2009, 'Urban planning in Poland in the context of European standards', Quaestiones Geographicae, vol. 28B, pp. 29-37. 
Parysek, JJ 2009, 'Urban development in Poland after 2003: Legal regulations and reality', Quaestiones Geographicae, vol. 28B, pp. 39-47.

Patrykiejew, A 1998, Wprowadzenie do metody Monte Carlo, Wyd. UMCS, Lublin.

Prawelska-Skrzypek, G 1985, System użytkowania przestrzeni miejskiej Rzeszowa, Muzeum Okręgowe, Rzeszów.

Ratajczak, W 1999, Modelowanie sieci transportowych, Wydawnictwo naukowe Uniwersytetu Adama Mickiewicza, Poznań.

Research Randomizer 4.0, on-line application. Available from: <http://www.randomizer.org>. [21.06.2014].

Shi, P, Yuan, Y, He, CY, Li, X \& Chen, Y 2004, 'Land Use Pattern Adjustment under Ecological Security - Look for Secure Land Use Pattern in China', Geographical Review of Japan, vol. 77 , no.12, pp. 866-882.

Sobalski, F 1974, 'Zarys historii gospodarczej powiatu częstochowskiego do 1939 r.', Ziemia Częstochowska, vol. X ed M Stańczyk, Towarzystwo Popierania Kultury Regionalnej, Częstochowa, pp. 143-163.

Studium uwarunkowań i kierunków zagospodarowania przestrzennego gminy Mstów (Study of conditions and directions of spatial development for the Mstów municipality) 2012. Urząd Gminy w Mstowie (The Municipality Office of Mstów). Available from: <http://www.mstow.pl/gmina-mstow/ studium-uwarunkowan-gm-mstow.html>. [15 June 2014]. Also officially submitted for inspection to author.
Terando, AJ, Costanza, J, Belyea, C, Dunn, RR, McKerrow, A \& Collazo, JA 2014, 'The Southern Megalopolis: Using the Past to Predict the Future of Urban Sprawl in the Southeast U.S', PLoS ONE vol. 9(7): e102261. Available from: <http:// journals.plos.org/plosone/article?id=10.1371/journal. pone.0102261>. [28 November 2015].

Ustawa z dnia 27 marca 2003 r. o planowaniu i zagospodarowaniu przestrzennym (Physical Planning and Spatial Development Act 2003) (Dz. U. $2003 \mathrm{Nr} 80$ poz. 717). Available from: <http:// isap.sejm.gov.pl/DetailsServlet?id=WDU20030800717>. [22 October 2014].

Warszynska, J 1980, 'The application of the simulation method Monte Carlo to forecast spatial distribution of tourist movement', Folia Geographica; Series GeographicaOeconomica, vol. 13, pp. 73-84.

Werner, P 2003, Geograficzne uwarunkowania rozwoju infrastruktury społeczeństwa informacyjnego w Polsce, Uniwersytet Warszawski, Warszawa.

Wolski, O 2014, 'Suburbanizacja zewnętrzna wsi a specyfika obszaru podmiejskiego na przykładzie Mstowa' ("The outer suburbanisation in relation to the specification of suburban area on the example of Mstów"), master thesis defended on 1 July 2014, Institute of Geography and Spatial Management, Jagiellonian University, Kraków.

Zdjęcie topogr. ros. z r. 1893 (Topographic image 1893): Olsztyn, Częstochowa, Mstów, (no author). 